\title{
Physiologic parameters variation in ICR mice during a chemical induced liver carcinogenesis experiment
}

\author{
Ivo Conceição-Pereira ${ }^{1 \dagger}$, Nuno M Paula-Santos ${ }^{1 \dagger}$, Filipa O Pereira' ${ }^{1}$, Maria J Pires ${ }^{1}$, Luis F Palomino ${ }^{2}$, Aura A Colaço ${ }^{1}$, \\ Paula A Oliveira ${ }^{* *}$
}

From 16th International Charles Heidelberger Symposium on Cancer Research

Coimbra, Portugal. 26-28 September 2010

Hepatocellular carcinoma (HCC) is responsible for more then 600000 deaths worldwide. HCC accounts for 85 to $90 \%$ of primary liver cancers [1]. Laboratory mouse is one of the best animal models to study cancer in vivo due to various features like the similarities to humans. Animal models that mimic human diseases are quite important to understand biopathology mechanisms underlying those diseases [2].

$\mathrm{N}$-diethylnitrosamine (DEN) is a genotoxic carcinogen activated by a P450-dependent mono-oxigenase into a highly reactive molecule that will affect liver tissue [3].

The aim of this study was to evaluate the effect of DEN on 5 weeks old male ICR mice physiologic parameters. Mice were euthanized 7 and 14 weeks after last DEN injections. A thorough necropsy was performed and registered the weight and macroscopic evaluation of organs. Blood for hematocrit analysis was collected by cardiac puncture.

Some animals of the experimental group developed visible alterations in the liver. Significant values in biochemistry parameters between control/experimental groups were determined to alanine aminotransferase $(\mathrm{p}=0.044)$ and total bilirrubin $(\mathrm{p}=0.026)$.

Mean weight values were also significant between groups in the first euthanized mice $(\mathrm{p}=0.048)$.

\section{Author details}

${ }^{1}$ CECAV, Department of Veterinary Sciences, University of Trás-os-Montes e Alto Douro, Vila Real, Portugal. ${ }^{2}$ Department of Physiology, Veterinary Faculty, University of Santiago de Compostela, Lugo, Spain.

\footnotetext{
* Correspondence: pamo@utad.pt

+ Contributed equally

${ }^{1}$ CECAV, Department of Veterinary Sciences, University of Trás-os-Montes e Alto Douro, Vila Real, Portugal

Full list of author information is available at the end of the article
}

\section{Published: 24 September 2010}

References

1. Schütte K, Bornschein J, Malfertheiner P: HCC: epidemiological trends and risk factors. Dig Dis 2009, 27:80-92.

2. Leenders $M$, Nijkamp M, Rinkes I: Mouse models in liver cancer research: a view of current literature. Worl J Gastroenterol 2008, 14:6915-6923.

3. Lahm H, Gittner K, Krebs O, Sprague L, Deml E, Oesterle D, Hoeflich A, Wanke $\mathrm{R}$, Wolf E: Diethylnitrosamine induces long-lasting re-expression of insulin-like growth factor II during early stages of liver carcinogenesis in mice. Growth Horm IGF Res 2002, 12:69-79.

\section{doi:10.3748/wjg.14.6915}

Cite this article as: Conceição-Pereira et al:: Physiologic parameters variation in ICR mice during a chemical induced liver carcinogenesis experiment. BMC Proceedings 2010 4(Suppl 2):P33.
Submit your next manuscript to BioMed Central and take full advantage of:

- Convenient online submission

- Thorough peer review

- No space constraints or color figure charges

- Immediate publication on acceptance

- Inclusion in PubMed, CAS, Scopus and Google Scholar

- Research which is freely available for redistribution

Submit your manuscript at www.biomedcentral.com/submit
C Biomed Central 